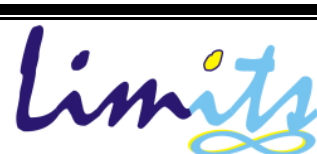

Limits: Journal of Mathematics and Its Applications

E-ISSN: 2579-8936

P-ISSN: 1829-605X

Vol. 17, No. 2, Desember 2020, 111-121

DOI: http://dx.doi.org/10.12962/limits.v17i2.5253

\title{
Perhitungan Matematika Pada Peluang Inbreeding Dalam Populasi Ternak Generasi Pertama
}

\author{
Widya Pintaka Bayu Putra ${ }^{1}$, Muhammad Firmansyah ${ }^{2}$ \\ ${ }^{1}$ Pusat Penelitian Bioeknologi, Lembaga Ilmu Pengetahuan Indonesia, \\ ${ }^{2}$ Fakultas Matematika dan Ilmu Pengetahuan Alam, Institut Pertanian Bogor, Indonesia \\ e-mail: widya.putra.lipi@gmail.com ${ }^{1}$, firmanmath@gmail.com ${ }^{2}$
}

Diajukan:26 Mei 2019, Diperbaiki: 15 September 2020, Diterima:27 Nopember 2020

\begin{abstract}
Abstrak
Level inbreeding yang tinggi pada ternak dapat menyebabkan dampak ekonomi yang besar karena dapat menurunkan produktivitas ternak antara lain berat badan, berat karkas, produksi susu dan kinerja reproduksi. Penelitian ini bertujuan untuk menyusun formula matematika secara trial and error method untuk menghitung peluang terjadinya inbreeding pada populasi ternak generasi pertama (F1). Penelitian ini dilakukan dengan dua skenario sistem perkawinan yaitu kawin alam (KA) dan inseminasi buatan (IB). Asumsi yang digunakan adalah nilai service per conception $(S / C)$ sebesar 1,00 , jumlah betina $\left(\mathrm{N}_{\mathrm{D}}\right)$ dan straw $\left(\mathrm{N}_{\mathrm{Str}}\right)$ pada sistem IB sama, generasi pertama pada sistem KA dan IB terjadi secara acak (random) dan setiap induk memiliki satu anak (progeny). Parameter yang diamati yaitu peluang inbreeding pada generasi pertama $\left(\mathrm{P}_{\mathrm{I}}\right)$, jumlah kombinasi perkawinan pada tetua $\left(\mathrm{N}_{\mathrm{MP}}\right)$, jumlah kombinasi perkawinan pada generasi pertama $\left(\mathrm{N}_{\mathrm{MG}}\right)$, jumlah kombinasi perkawinan inbreeding pada sistem KA ( $\left.\mathrm{N}_{\mathrm{MI}}\right)$ dan IB $\left(\mathrm{N}_{\mathrm{MK}}\right)$. Hasil penelitian menunjukkan bahwa formula matematika yang telah diperoleh dapat digunakan untuk menghitung nilai $P_{i}$ pada kedua sistem perkawinan dan telah teruji melalui simulasi data.

Kata Kunci : Generasi Pertama, Manajemen Perkawinan, Populasi Ternak, Peluang Inbreeding, Formula Matematika.

Abstract

Highly inbreeding level in the livestock had high economic impact because of low productivity on body weight, carcass weight, milk yield and reproductive traits. This research was carried out to obtain the mathematical formula with trial and error method to estimate inbreeding probability in the livestock population. This research was conducted with two mating system scenarios of natural mating (KA) and artificial insemination (IB). The assumption that used in this study are service per conception $(S / C)$ was 1.00 , similar number of dam $\left(N_{D}\right)$ and straw $\left(N_{S t r}\right)$ in IB method, random mating was occured in the first generation of $K A$ and IB systems and each dam had one offspring. Meanwhile, the parameters that observe were inbreeding probability $\left(P_{I}\right)$, number of mating combination in parents $\left(N_{M P}\right)$, number of mating combination in first generation $\left(N_{M G}\right)$ and number of inbreeding mating combination in $K A\left(N_{M I}\right)$ and $I B$ $\left(N_{M K}\right)$ systems. The mathematics formula that created in this study can be used to calculate $P_{i}$ value in both mating systemsand has been tested with data simulation.
\end{abstract}

Keywords : First Generation, Mating Management, Livestock Population, Inbreeding Probability, Mathematical Formula 


\section{Pendahuluan}

Inbreeding atau silang dalam pada ternak dapat disebabkan karena sistem perkawinan yang jelek. Umumnya inbreeding pada ternak terjadi pada peternakan rakyat karena sebagian besar peternak tradisional memelihara ternak secara ekstensif tanpa melakukan pencatatan ternak (recording). Akibatnya, perkawinan antar ternak yang masih memiliki hubungan kekerabatan akan terjadi dan apabila terjadi secara terus dapat menyebabkan produktivitas ternak akan turun dari generasi ke generasi [1]. Selain itu, dampak yang paling parah akibat perkawinan inbreeding secara terus menerus adalah memunculkan individu yang cacat secara genetik [2].

Dalam teori pemuliaan ternak, besarnya tekanan inbreeding atau koefisien silang dalam $\left(\mathrm{F}_{\text {is }}\right)$ pada suatu individu dapat dihitung berdasarkan formula yang sudah ada sebelumnya [1]. Akan tetapi, peluang terjadinya inbreeding pada generasi pertama dalam suatu populasi ternak sejauh ini belum ada yang mengkaji. Estimasi peluang inbreeding dalam populasi ternak sangat penting untuk mengevaluasi kebutuhan jumlah pejantan dan berapa jumlah sperma beku (straw) yang harus dihasilkan pada suatu populasi ternak betina.

Saat ini telah ditemukan formula matematika untuk menghitung level (koefisien) inbreeding pada individu ternak menggunakan catatan data silsilah ternak. Akan tetapi formula matematika untuk menghitung besarnya peluang inbreeding dalam suatu populasi ternak belum ditemukan. Penelitian ini bertujuan untuk memperoleh formula matematika untuk menghitung peluang inbreeding $\left(\mathrm{P}_{\mathrm{i}}\right)$ pada generasi pertama $(\mathrm{F} 1)$ dalam suatu populasi ternak pada sistem perkawinan yang berbeda yaitu kawin alam (KA) dan inseminasi buatan (IB). Manfaat penelitian adalah dapat digunakan sebagai bahan evaluasi untuk menentukan jumlah pejantan yang harus dipelihara dan jumlah dosis straw yang harus diproduksi di Balai Besar Inseminasi Buatan (BBIB) milik pemerinatah maupun perusahaan peternakan swasta agar nilai $\mathrm{P}_{\mathrm{i}}$ pada populasi $\mathrm{F} 1$ kurang dari $50 \%$.

\section{Metode Penelitian}

\subsection{Asumsi Penelitian}

Beberapa asumsi diperlukan dalam penelitian ini agar diperoleh pola data yang benar. Asumsi dalam penelitian ini dilakukan pada kondisi manajemen dan populasi ternak sebagai berikut:

1. Perhitungan peluang inbreeding dilakukan pada generasi pertama

2. Jumlah banyaknya perkawinan sampai terjadi kebuntingan atau service per conception $(S / C)$ pada sistem IB adalah 1,00. 
3. Pada sistem KA, perkawinan pada tetua dan antar generasi pertama terjadi secara acak (random)

4. Pada sistem IB, perkawinan pada tetua terjadi secara tidak acak (ditentukan) tetapi perkawinan antar generasi pertama terjadi secara acak

5. Pada sistem IB jumlah betina sama dengan jumlah sperma beku (straw)

6. Pada setiap sistem perkawinan masing-masing induk menghasilkan satu anak (progeny)

\subsection{Formulasi Matematika}

Perhitungan formula matematika untuk estimasi peluang inbreeding dilakukan menggunakan program komputer Microsoft Excel 2007. Pola runutan angka yang diperoleh selanjutnya dianalisis untuk mendapatkan formula matematika secara trial and error method. Analisis pada PI dilakukan berdasarkan skema perkawinan ternak seperti pada Gambar 1 sebagai berikut:

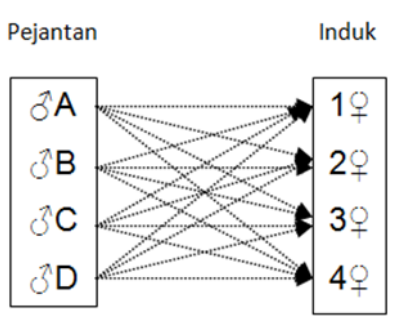

Sistem KA

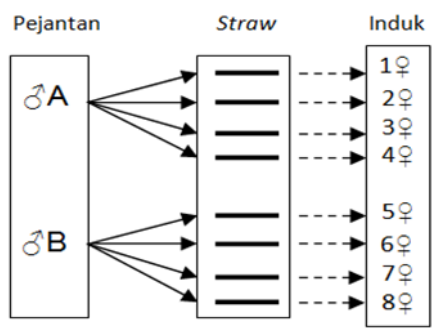

Sistem IB

Gambar 1. Skema perkawinan ternak pada sistem kawin alam (KA) dan inseminasi buatan (IB)

Pada sistem KA, setiap pejantan memiliki peluang untuk mengawini semua betina. Pada sistem ini jumlah kombinasi perkawinan pada tetua dan pada generasi pertama dapat dihitung menggunakan formula matematika yang telah diperoleh berdasarkan hasil simulasi data secara trial and error method sebagai berikut:

$$
\begin{aligned}
& \mathrm{N}_{M P}=\mathrm{N}_{S} \times \mathrm{N}_{D} \\
& \mathrm{~N}_{M G}=\left(\mathrm{N}_{M P}-1\right) \times\left[\left(\mathrm{N}_{S} \times \mathrm{N}_{D}\right) / 2\right] \\
& \mathrm{N}_{M G}=\left(\mathrm{N}_{M P}-1\right) \times\left(\mathrm{N}_{M P} \times 0,50\right)
\end{aligned}
$$

dengan $\mathrm{N}_{\mathrm{MP}}=$ jumlah kombinasi perkawinan pada tetua/parental; $\mathrm{N}_{\mathrm{MG}}=$ jumlah kombinasi perkawinan pada generasi pertama; $\mathrm{N}_{\mathrm{S}}=$ jumlah ternak jantan (ekor) dan $\mathrm{N}_{\mathrm{D}}=$ jumlah ternak betina (ekor)

Nilai $\mathrm{N}_{M P}$ dan $\mathrm{N}_{M G}$ tersebut selanjutnya digunakan untuk menghitung estimasi peluang inbreeding $\left(\mathrm{P}_{\mathrm{I}}\right)$ berdasarkan formula peluang dasar [3] sebagai berikut:

$$
\mathrm{P}_{\mathrm{I}}=\mathrm{N}_{\mathrm{MI}} / \mathrm{N}_{\mathrm{MG}}
$$


dan nilai $\mathrm{N}_{\mathrm{MI}}$ dihitung menggunakan persamaan sebagai berikut:

$$
\begin{aligned}
& \mathrm{N}_{\mathrm{MI}}=\left[\left(\mathrm{N}_{\mathrm{S}}+\mathrm{N}_{\mathrm{D}}\right)-2\right] \times\left(\mathrm{N}_{\mathrm{S}} \times \mathrm{N}_{\mathrm{D}}\right) \times 0,50 \\
& \mathrm{~N}_{\mathrm{MI}}=\left[\left(\mathrm{N}_{\mathrm{S}}+\mathrm{N}_{\mathrm{D}}\right)-2\right] \times \mathrm{N}_{\mathrm{MP}} \times 0,50
\end{aligned}
$$

Dengan $\mathrm{P}_{\mathrm{I}}=$ peluang inbreeding; $\mathrm{N}_{\mathrm{MI}}=$ jumlah kombinasi perkawinan inbreeding pada generasi pertama; $\mathrm{N}_{\mathrm{S}}=$ jumlah ternak jantan (ekor) dan $\mathrm{N}_{\mathrm{D}}=$ jumlah ternak betina (ekor)

Pada sistem IB, setiap pejantan akan menghasilkan banyak dosis sperma beku (straw) yang selanjutnya digunakan untuk kawin suntik pada ternak betina seperti pada Gambar 1. Berdasarkan Gambar 1 tersebut secara tidak langsung peluang ternak jantan untuk mengawini ternak betina dipengaruhi oleh banyaknya straw yang dihasilkan. Semakin banyak ternak jantan menghasilkan straw maka semakin banyak ternak betina yang dikawini melalui teknik IB. Pada kondisi tersebut, maka jumlah kombinasi perkawinan pada tetua dan pada generasi pertama dapat dihitung menggunakan persamaan yang telah diperoleh secara trial and error method sebagai berikut:

$$
\begin{aligned}
& \mathrm{N}_{\mathrm{MP}}=\mathrm{N}_{\mathrm{Str}} \\
& \mathrm{N}_{\mathrm{MG}}=\left(\mathrm{N}_{\mathrm{MP}}-1\right) \times\left(\mathrm{N}_{\mathrm{MP}} \times 0,50\right)
\end{aligned}
$$

dimana $\mathrm{N}_{\text {Str }}=$ jumlah sperma beku/straw (dosis); $\mathrm{N}_{\mathrm{MP}}=$ jumlah kombinasi perkawinan pada tetua/parental; $\mathrm{N}_{\mathrm{MG}}=$ jumlah kombinasi perkawinan pada generasi pertama.

Nilai $\mathrm{N}_{\mathrm{MP}}$ dan $\mathrm{N}_{\mathrm{MG}}$ tersebut selanjutnya digunakan untuk menghitung peluang inbreeding ( $\mathrm{P}$ ) menggunakan formula matematika yang telah diperoleh berdasarkan hasil simulasi data secara trial and error method sebagai berikut:

$$
\mathrm{PI}_{\mathrm{I}}=\mathrm{N}_{\mathrm{MK}} / \mathrm{N}_{\mathrm{MG}}
$$

dengan nilai $\mathrm{N}_{\mathrm{MK}}$ diperoleh menggunakan formula yang diperoleh melalui trial and error method sebagai berikut:

$$
\begin{aligned}
& \mathrm{N}_{\mathrm{MK}}=\sum_{\mathrm{i}=1}^{\mathrm{n}} \mathrm{k}_{\mathrm{i}} \times\left(\mathrm{k}_{\mathrm{i}}-1\right) \times 0,50 \\
& \mathrm{~N}_{\mathrm{MK}}=\frac{\left[\mathrm{k}_{1} \times\left(\mathrm{k}_{1}-1\right)\right]+\left[\mathrm{k}_{2} \times\left(\mathrm{k}_{2}-1\right)\right]+\ldots \ldots \ldots . .\left[\mathrm{k}_{\mathrm{n}} \times\left(\mathrm{k}_{\mathrm{n}}-1\right)\right]}{2}
\end{aligned}
$$

dimana $\mathrm{P}_{\mathrm{I}}=$ peluang inbreeding; $\mathrm{k}_{\mathrm{i}}=$ jumlah straw pejantan ke-i (dosis); $\mathrm{N}_{\mathrm{S}}=$ jumlah pejantan (ekor); $\mathrm{N}_{\mathrm{MK}}=$ jumlah kombinasi perkawinan inbreeding pada generasi pertama; $\mathrm{N}_{\mathrm{Str}}=$ jumlah straw total (dosis).

\subsection{Simulasi Data}

Simulasi data pada penelitian ini dilakukan untuk menguji kesesuaian hasil simulasi data berdasarkan formula matematika yang telah diperoleh menggunakan program komputer Microsoft 
Excel 2007 secara trial and error method. Simulasi ini dilakukan untuk menguji kesesuaian hasil perhitungan terhadap konsep teori inbreeding pada ilmu pemuliaan ternak.

\section{Hasil dan Pembahasan}

\subsection{Hasil Simulasi Data}

Simulasi data untuk menghitung $\mathrm{P}_{\mathrm{I}}$ pada sistem KA dilakukan pada contoh populasi ternak dengan jumlah jantan $\left(\mathrm{N}_{S}\right)$ sebesar 4 ekor (A,B,C.D) dan jumlah betina $\left(\mathrm{N}_{\mathrm{D}}\right)$ sebesar 4 ekor $(1,2,3,4)$. Maka peluang inbreeding $\left(\mathrm{P}_{\mathrm{I}}\right)$ pada generasi pertama menurut formula matematika yang telah diperoleh sebagai berikut:

$$
\begin{aligned}
\mathrm{N}_{M P} & =\mathrm{N}_{\mathrm{S}} \times \mathrm{N}_{\mathrm{D}} \\
& =4 \times 4 \\
& =16 \text { kombinasi }(\text { Tabel } 1) \\
\mathrm{N}_{M G} & \left.=\mathrm{N}_{\mathrm{MP}}-1\right) \times\left(\mathrm{N}_{\mathrm{MP}} \times 0,50\right) \\
& =(16-1) \times(16 / 2) \\
& =120 \mathrm{kombinasi}(\text { Tabel } 2) \\
\mathrm{P}_{\mathrm{I}} & =\mathrm{N}_{\mathrm{MI}} / \mathrm{N}_{\mathrm{MG}} \\
\mathrm{N}_{\mathrm{MI}} & =[(4+4)-2] \times(4 \times 4) \times 0,50 \\
& =6 \times 16 \times 0,50 \\
& =48 \mathrm{kombinasi}(\text { Tabel } 2) \\
\mathrm{PI}_{\mathrm{I}} & =48 / 120 \\
& =0,40
\end{aligned}
$$

\begin{tabular}{|c|c|c|c|c|c|c|c|}
\hline No. & $\begin{array}{c}\text { Pejantan } \\
\left({ }^{\lambda}\right)\end{array}$ & $\begin{array}{c}\text { Betina } \\
((P)\end{array}$ & Anak & No. & $\begin{array}{c}\text { Pejantan } \\
\left({ }^{\pi}\right)\end{array}$ & $\begin{array}{c}\text { Betina } \\
(())\end{array}$ & Anak \\
\hline 1 & $\mathrm{~A}$ & 1 & A1 & 9 & $\mathrm{C}$ & 1 & $\mathrm{C} 1$ \\
\hline 2 & A & 2 & A2 & 10 & $\mathrm{C}$ & 2 & $\mathrm{C} 2$ \\
\hline 3 & A & 3 & A3 & 11 & $\mathrm{C}$ & 3 & $\mathrm{C} 3$ \\
\hline 4 & A & 4 & A4 & 12 & $\mathrm{C}$ & 4 & $\mathrm{C} 4$ \\
\hline 5 & B & 1 & B1 & 13 & D & 1 & D1 \\
\hline 6 & B & 2 & B2 & 14 & D & 2 & D2 \\
\hline 7 & B & 3 & B3 & 15 & D & 3 & D3 \\
\hline 8 & B & 4 & B4 & 16 & D & 4 & D4 \\
\hline
\end{tabular}

Tabel 1. Kombinasi perkawinan pada tetua untuk menghasilkan generasi pertama pada sistem KA

Tabel 2. Kombinasi perkawinan pada generasi pertama pada sistem KA

\begin{tabular}{cccccccc}
\hline No. & Pejantan $\left({ }^{\AA}\right)$ & Betina $(+)$ & Keterangan & No. & Pejantan $\left({ }^{\AA}\right)$ & Betina $(+)$ & Keterangan \\
\hline 1 & A1 & A2 & inbreeding & 61 & B1 & C4 & - \\
2 & A1 & A3 & inbreeding & 62 & B1 & D1 & inbreeding \\
3 & A1 & A4 & inbreeding & 63 & B1 & D2 & - \\
\hline
\end{tabular}




\begin{tabular}{|c|c|c|c|c|c|c|c|}
\hline No. & Pejantan( $\left(0^{\wedge}\right)$ & Betina(O) & Keterangan & No. & Pejantan $\left(0^{\wedge}\right)$ & Betina $(O)$ & Keterangan \\
\hline 4 & $\mathrm{~A} 1$ & $\mathrm{~B} 1$ & inbreeding & 64 & B1 & D3 & - \\
\hline 5 & A1 & B2 & - & 65 & B1 & D4 & - \\
\hline 6 & A1 & B3 & - & 66 & B2 & B3 & inbreeding \\
\hline 7 & A1 & B4 & - & 67 & B2 & B4 & inbreeding \\
\hline 8 & A1 & $\mathrm{C} 1$ & inbreeding & 68 & B2 & $\mathrm{C} 1$ & - \\
\hline 9 & A1 & $\mathrm{C} 2$ & - & 69 & B2 & $\mathrm{C} 2$ & inbreeding \\
\hline 10 & A1 & $\mathrm{C} 3$ & - & 70 & B2 & C3 & - \\
\hline 11 & A1 & $\mathrm{C} 4$ & - & 71 & B2 & $\mathrm{C} 4$ & - \\
\hline 12 & A1 & D1 & inbreeding & 72 & B2 & D1 & - \\
\hline 13 & A1 & D2 & - & 73 & B2 & D2 & inbreeding \\
\hline 14 & A1 & D3 & - & 74 & B2 & D3 & - \\
\hline 15 & A1 & D4 & - & 75 & B2 & D4 & - \\
\hline 16 & A2 & A3 & inbreeding & 76 & B3 & B4 & inbreeding \\
\hline 17 & A2 & A4 & inbreeding & 77 & B3 & $\mathrm{C} 1$ & - \\
\hline 18 & A2 & B1 & - & 78 & B3 & $\mathrm{C} 2$ & - \\
\hline 19 & A2 & B2 & inbreeding & 79 & B3 & C3 & inbreeding \\
\hline 20 & A2 & B3 & - & 80 & B3 & $\mathrm{C} 4$ & - \\
\hline 21 & A2 & B4 & - & 81 & B3 & D1 & - \\
\hline 22 & A2 & $\mathrm{C} 1$ & - & 82 & B3 & D2 & - \\
\hline 23 & A2 & $\mathrm{C} 2$ & inbreeding & 83 & B3 & D3 & inbreeding \\
\hline 24 & A2 & $\mathrm{C} 3$ & - & 84 & B3 & D4 & - \\
\hline 25 & A2 & $\mathrm{C} 4$ & - & 85 & B4 & $\mathrm{C} 1$ & - \\
\hline 26 & A2 & D1 & - & 86 & B4 & $\mathrm{C} 2$ & - \\
\hline 27 & A2 & D2 & inbreeding & 87 & B4 & $\mathrm{C} 3$ & - \\
\hline 28 & A2 & D3 & - & 88 & B4 & $\mathrm{C} 4$ & inbreeding \\
\hline 29 & A2 & D4 & - & 89 & B4 & D1 & - \\
\hline 30 & A3 & A4 & inbreeding & 90 & B4 & D2 & - \\
\hline 31 & A3 & B1 & - & 91 & B4 & D3 & - \\
\hline 32 & A3 & B2 & - & 92 & B4 & D4 & inbreeding \\
\hline 33 & A3 & B3 & inbreeding & 93 & $\mathrm{C} 1$ & $\mathrm{C} 2$ & inbreeding \\
\hline 34 & A3 & B4 & - & 94 & $\mathrm{C} 1$ & $\mathrm{C} 3$ & inbreeding \\
\hline 35 & A3 & $\mathrm{C} 1$ & - & 95 & $\mathrm{C} 1$ & $\mathrm{C} 4$ & inbreeding \\
\hline 36 & A3 & $\mathrm{C} 2$ & - & 96 & $\mathrm{C} 1$ & D1 & inbreeding \\
\hline 37 & A3 & $\mathrm{C} 3$ & inbreeding & 97 & $\mathrm{C} 1$ & D2 & - \\
\hline 38 & A3 & $\mathrm{C} 4$ & - & 98 & $\mathrm{C} 1$ & D3 & - \\
\hline 39 & A3 & D1 & - & 99 & $\mathrm{C} 1$ & D4 & - \\
\hline 40 & A3 & D2 & - & 100 & $\mathrm{C} 2$ & $\mathrm{C} 3$ & inbreeding \\
\hline 41 & A3 & D3 & inbreeding & 101 & $\mathrm{C} 2$ & $\mathrm{C} 4$ & inbreeding \\
\hline 42 & A3 & D4 & - & 102 & $\mathrm{C} 2$ & D1 & - \\
\hline 43 & A4 & B1 & - & 103 & $\mathrm{C} 2$ & D2 & inbreeding \\
\hline 44 & A4 & B2 & - & 104 & $\mathrm{C} 2$ & D3 & - \\
\hline 45 & A4 & B3 & - & 105 & $\mathrm{C} 2$ & D4 & - \\
\hline 46 & A4 & B4 & inbreeding & 106 & C3 & $\mathrm{C} 4$ & inbreeding \\
\hline 47 & A4 & $\mathrm{C} 1$ & - & 107 & $\mathrm{C} 3$ & D1 & - \\
\hline 48 & A4 & $\mathrm{C} 2$ & - & 108 & $\mathrm{C} 3$ & D2 & - \\
\hline 49 & A4 & $\mathrm{C} 3$ & - & 109 & C3 & D3 & inbreeding \\
\hline 50 & A4 & $\mathrm{C} 4$ & inbreeding & 110 & $\mathrm{C} 3$ & D4 & - \\
\hline 51 & A4 & D1 & - & 111 & $\mathrm{C} 4$ & D1 & - \\
\hline 52 & A4 & D2 & - & 112 & $\mathrm{C} 4$ & D2 & - \\
\hline 53 & A4 & D3 & - & 113 & $\mathrm{C} 4$ & D3 & - \\
\hline 54 & A4 & D4 & inbreeding & 114 & $\mathrm{C} 4$ & D4 & inbreeding \\
\hline 55 & B1 & B2 & inbreeding & 115 & D1 & D2 & inbreeding \\
\hline 56 & B1 & B3 & inbreeding & 116 & D1 & D3 & inbreeding \\
\hline 57 & B1 & B4 & inbreeding & 117 & D1 & D4 & inbreeding \\
\hline 58 & B1 & $\mathrm{C} 1$ & inbreeding & 118 & D2 & D3 & inbreeding \\
\hline 59 & B1 & $\mathrm{C} 2$ & 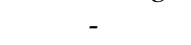 & 119 & D2 & D4 & inbreeding \\
\hline 60 & B1 & $\mathrm{C} 3$ & - & 120 & D3 & D4 & inbreeding \\
\hline
\end{tabular}


Simulasi data sederhana untuk menghitung PI pada sistem IB dilakukan pada contoh sebagai berikut: Terdapat 3 ekor pejantan penghasil straw yaitu A (4 dosis), B (3 dosis) dan C (2 dosis). Dengan asumsi $\mathrm{S} / \mathrm{C}=1,00$ dan jumlah induk sama dengan jumlah straw, maka peluang inbreeding pada generasi pertama (PI) dapat diperoleh sebagai berikut:

$\mathrm{N}_{\mathrm{MP}}=\mathrm{NStr}_{\mathrm{s}}=4+3+2=9$ kombinasi $($ Tabel 3)

$$
\begin{aligned}
& \mathrm{N}_{\mathrm{MG}}=\left(\mathrm{N}_{\mathrm{MP}}-1\right) \times\left(\mathrm{N}_{\mathrm{MP}} \times 0,50\right) \\
&=(9-1) \times(9 \times 0,50) \\
&=8 \times 4,5 \\
&=36 \text { kombinasi (Tabel } 4) \\
& \mathrm{N}_{\mathrm{MK}}=\sum_{\mathrm{i}=1}^{\mathrm{n}} \mathrm{k}_{\mathrm{i}} \times\left(\mathrm{k}_{\mathrm{i}}-1\right) \times 0,50 \\
&=\frac{4 \times(4-1)}{2}+\frac{3 \times(3-1)}{2}+\frac{2 \times(2-1)}{2} \\
&=6+3+1 \\
&=10 \mathrm{kombinasi}(\mathrm{Tabel} 4) \\
&=\mathrm{N}_{\mathrm{Mk}} / \mathrm{N}_{\mathrm{MG}} \\
&=10 / 36 \\
&=0,28
\end{aligned}
$$

Tabel 3. Kombinasi perkawinan pada tetua untuk menghasilkan generasi pertama pada sistem IB

\begin{tabular}{cccc}
\hline No. & Straw & Induk & Anak \\
\hline 1 & A & 1 & A1 \\
2 & A & 2 & A2 \\
3 & A & 3 & A3 \\
4 & A & 4 & A4 \\
5 & B & 5 & B5 \\
6 & B & 6 & B6 \\
7 & B & 7 & B7 \\
8 & C & 8 & C8 \\
9 & C & 9 & C9 \\
\hline
\end{tabular}

Tabel 4. Kombinasi perkawinan pada generasi pertama pada sistem IB

\begin{tabular}{cccccccc}
\hline No & $\begin{array}{c}\text { Pejantan } \\
\left({ }^{\lambda}\right)\end{array}$ & $\begin{array}{c}\text { Induk } \\
(+)\end{array}$ & Keterangan & No & Pejantan $\left(\bigcirc^{\lambda}\right)$ & $\begin{array}{c}\text { Induk } \\
(+)\end{array}$ & Keterangan \\
\hline 1 & A1 & A2 & inbreeding & 19 & A3 & B7 & - \\
2 & A1 & A3 & inbreeding & 20 & A3 & C8 & - \\
3 & A1 & A4 & inbreeding & 21 & A3 & C9 & - \\
4 & A1 & B5 & - & 22 & A4 & B5 & - \\
5 & A1 & B6 & - & 23 & A4 & B6 & - \\
6 & A1 & B7 & - & 24 & A4 & B7 & - \\
7 & A1 & C8 & - & 25 & A4 & C8 & - \\
8 & A1 & C9 & - & 26 & A4 & C9 & - \\
9 & A2 & A3 & inbreeding & 27 & B5 & B6 & inbreeding \\
\hline
\end{tabular}




\begin{tabular}{|c|c|c|c|c|c|c|c|}
\hline No & $\begin{array}{c}\text { Pejantan } \\
\left(0^{\pi}\right)\end{array}$ & $\begin{array}{c}\text { Induk } \\
\left(\begin{array}{l}\text { ( }) \\
\end{array}\right.\end{array}$ & Keterangan & No & Pejantan $\left(\widehat{O}^{\lambda}\right)$ & $\begin{array}{c}\text { Induk } \\
\left(\begin{array}{l}\text { ( }) \\
\end{array}\right.\end{array}$ & Keterangan \\
\hline 10 & A2 & A4 & inbreeding & 28 & B5 & B7 & inbreeding \\
\hline 11 & $\mathrm{~A} 2$ & B5 & - & 29 & B5 & $\mathrm{C} 8$ & - \\
\hline 12 & A2 & B6 & - & 30 & B5 & C9 & - \\
\hline 13 & A2 & B7 & - & 31 & B6 & B7 & inbreeding \\
\hline 14 & A2 & $\mathrm{C} 8$ & - & 32 & B6 & C7 & - \\
\hline 15 & A2 & C9 & - & 33 & B6 & $\mathrm{C} 8$ & - \\
\hline 16 & A3 & A4 & inbreeding & 34 & B7 & $\mathrm{C} 8$ & - \\
\hline 17 & A3 & B5 & - & 35 & B7 & C9 & - \\
\hline 18 & A3 & B6 & - & 36 & $\mathrm{C} 8$ & C9 & inbreeding \\
\hline
\end{tabular}

Simulasi data pada sistem IB menggunakan data produksi straw yang sebenarnya sebagai berikut: Balai Pengembangan Perbibitan dan Inseminasi Buatan Ternak - Sapi Potong (BPPIBTSP) Cijeungjing, Ciamis, Jawa Barat pada tahun 2017 memiliki enam ekor pejantan sapi Pasundan untuk menghasilkan straw yaitu Keling (468 dosis), Bima (3.732 dosis), Reog (5.017 dosis), Rangga Sakti (1.383 dosis), Pakuan (1.368 dosis) dan Angga Praja (592 dosis) [4]. Dengan asumsi yang sama maka nilai PI pada kondisi tersebut adalah:

$\mathrm{N}_{\mathrm{S}}=6$ ekor

$\mathrm{N}_{\mathrm{MP}}=\mathrm{N}_{\mathrm{Str}}=468+3732+5017+1383+1368+592=12.560$ kombinasi

$\mathrm{N}_{\mathrm{MG}}=\left(\mathrm{N}_{\mathrm{MP}}-1\right) \times\left(\mathrm{N}_{\mathrm{MP}} \times 0,50\right)$

$=(12.560-1) \times(12.560 \times 0,50)$

$=12.559 \times 6.280$

$=78.870 .520$ kombinasi

$\mathrm{N}_{\mathrm{MK}}=\sum_{\mathrm{i}=1}^{\mathrm{n}} \mathrm{k}_{\mathrm{i}} \times\left(\mathrm{k}_{\mathrm{i}}-1\right) \times 0,50$

$=\frac{468 \times(468-1)}{2}+\frac{3732 \times(3702-1)}{2}+\frac{5017 \times(5017-1)}{2}+\frac{1383 \times(1383-1)}{2}+\frac{1368 \times(1368-1)}{2}+\frac{592-(592-1)}{2}$

$=218.556+13.924 .092+25165272+1.911 .306+1.870 .056+349.872$

$=43.439 .154$ kombinasi

PI $\quad=\mathrm{N}_{\mathrm{MK}} / \mathrm{N}_{\mathrm{MG}}$

$=43.439 .154 / 78.870 .520$

$=0,55$

3.2 Hubungan antara $\mathrm{N}_{S}$ dan $\mathrm{N}_{\mathrm{D}}$ Terhadap Pi pada Sistem KA

Hasil simulasi data pada sistem KA menunjukkan bahwa $\mathrm{N}_{S}$, dan $\mathrm{N}_{\mathrm{D}}$, merupakan dua komponen yang secara matematis mempengaruhi nilai $\mathrm{P}_{\mathrm{I}}$. Jika salah salah satu faktor nilainya semakin tinggi dan nilai faktor lainnya tidak berubah (tetap) maka nilai $\mathrm{P}_{\mathrm{I}}$ akan semakin rendah seperti pada Tabel 5. Selain itu terlihat juga bahwa semakin besar jumlah populasi $\left(\mathrm{N}_{S}+\mathrm{N}_{\mathrm{D}}\right)$ maka nilai PI akan semakin rendah. 
Dalam ilmu pemuliaan ternak, $\mathrm{N}_{S}$ dan $\mathrm{N}_{\mathrm{D}}$ merupakan komponen penting yang berpengaruh terhadap kemajuan genetik dalam populasi ternak [5]. Hasil simulasi data menjelaskan bahwa penggunaan pejantan dalam jumlah yang sedikit dapat menyebabkan resiko terjadinya perkawinan inbreeding per generasi menjadi besar. Hal ini sesuai dengan konsep ilmu pemuliaan ternak bahwa semakin banyak pejantan yang digunakan untuk program pembibitan dapat meningkatkan nilai kemajuan genetik [5]-[7]. Hal itu disebabkan karena keragaman genetik tetua dalam populasi akan semakin meningkat, sehingga peluang terjadinya inbreeding akan semakin menurun dan produktivitas ternak per generasi akan semakin meningkat [1], [2].

Tabel 5. Nilai peluang inbreeding $\left(\mathrm{P}_{\mathrm{I}}\right)$ pada sistem KA berdasarkan jumlah pejantan $\left(\mathrm{N}_{\mathrm{S}}\right)$ dan jumlah induk $\left(\mathrm{N}_{D}\right)$ yang berbeda

\begin{tabular}{ccccccccccc}
\hline \multirow{2}{*}{$\mathrm{N}_{\mathrm{S}}$} & \multicolumn{10}{c}{$\mathbf{8} \mathrm{N}_{\mathrm{D}}$} \\
\cline { 2 - 11 } & 1 & 2 & 3 & 4 & 5 & 6 & 7 & 8 & 9 & 10 \\
\hline 1 & - & 1,000 & 1,000 & 1,000 & 1,000 & 1,000 & 1,000 & 1,000 & 1,000 & 1,000 \\
2 & 1,000 & 0,667 & 0,600 & 0,571 & 0,556 & 0,545 & 0,538 & 0,533 & 0,529 & 0,526 \\
3 & 1,000 & 0,600 & 0,500 & 0,455 & 0,429 & 0,412 & 0,400 & 0,391 & 0,385 & 0,379 \\
4 & 1,000 & 0,571 & 0,455 & 0,400 & 0,368 & 0,348 & 0,333 & 0,323 & 0,314 & 0,308 \\
5 & 1,000 & 0,556 & 0,429 & 0,368 & 0,333 & 0,310 & 0,294 & 0,282 & 0,273 & 0,265 \\
6 & 1,000 & 0,545 & 0,412 & 0,348 & 0,310 & 0,286 & 0,268 & 0,255 & 0,245 & 0,237 \\
7 & 1,000 & 0,538 & 0,400 & 0,333 & 0,294 & 0,268 & 0,250 & 0,236 & 0,226 & 0,217 \\
8 & 1,000 & 0,533 & 0,391 & 0,323 & 0,282 & 0,255 & 0,236 & 0,222 & 0,211 & 0,203 \\
9 & 1,000 & 0,529 & 0,385 & 0,314 & 0,273 & 0,245 & 0,226 & 0,211 & 0,200 & 0,191 \\
10 & 1,000 & 0,526 & 0,379 & 0,308 & 0,265 & 0,237 & 0,217 & 0,203 & 0,191 & 0,182 \\
\hline
\end{tabular}

\subsection{Hubungan antara Ns,Nstr dan ki Terhadap Pi pada Sistem IB}

Hasil simulasi data pada sistem IB menunjukkan bahwa Ns, Nstr dan ki merupakan tiga komponen penting yang secara matematis mempengaruhi nilai P. Pada nilai Nstr yang tetap, nilai NS yang semakin meningkat menyebabkan nilai $P_{I}$ menjadi semakin kecil seperti pada Tabel 6. Selanjutnya, pada nilai $\mathrm{N}_{S}$ yang tetap, nilai $\mathrm{N}_{\text {Str }}$ yang semakin meningkat menyebabkan nilai $\mathrm{P}_{\mathrm{I}}$ menjadi semakin besar. Selain itu diketahui juga bahwa pada nilai Ns yang tetap, nilai ki yang semakin meningkat menyebabkan nilai $\mathrm{N}_{\mathrm{MK}}$ dan $\mathrm{P}_{\mathrm{I}}$ menjadi semakin meningkat.

Secara matematis dapat dijelaskan bahwa produksi straw sebanyak 100 dosis akan lebih baik jika dihasilkan dari 10 ekor pejantan dari pada 2 ekor pejantan, karena proporsi genetik tetua pada setiap individu akan lebih beragam dan peluang inbreeding per generasi menjadi lebih kecil. Selain itu, produksi straw dari pejantan secara terus menerus dapat meningkatkan nilai PI karena tidak ada keragaman genetik dari tetua. Hal ini mendukung konsep ilmu pemuliaan ternak bahwa semakin banyak jumlah pejantan yang digunakan untuk program pembibitan maka intensitas seleksi, kecermatan seleksi dan kemajuan genetik per generasi akan semakin meningkat [1]. 
Tabel 6. Nilai peluang inbreeding ( $\left.\mathrm{P}_{\mathrm{I}}\right)$ pada sistem IB berdasarkan nilai jumlah pejantan $\left(\mathrm{N}_{\mathrm{S}}\right)$ dan jumlah straw $\left(\mathrm{N}_{\mathrm{Str}}\right)$ yang berbeda*

\begin{tabular}{ccccccc}
\hline $\mathrm{N}_{\mathrm{S}}$ & $\mathrm{N}_{\mathrm{Str}}$ & $\mathrm{k}_{\mathrm{i}}$ & $\mathrm{N}_{\mathrm{MP}}$ & $\mathrm{N}_{\mathrm{MG}}$ & $\mathrm{N}_{\mathrm{MK}}$ & $\mathrm{P}_{\mathrm{I}}$ \\
\hline 1 & 100 & 100 & 100 & 4.950 & 4.950 & 1,00 \\
2 & 100 & 50 & 100 & 4.950 & 2.450 & 0,49 \\
3 & 100 & 33 & 100 & 4.950 & 1.617 & 0,33 \\
4 & 100 & 25 & 100 & 4.950 & 1.200 & 0,24 \\
5 & 100 & 20 & 100 & 4.950 & 950 & 0,19 \\
6 & 100 & 17 & 100 & 4.950 & 783 & 0,16 \\
7 & 100 & 14 & 100 & 4.950 & 664 & 0,13 \\
8 & 100 & 12 & 100 & 4.950 & 575 & 0,12 \\
9 & 100 & 11 & 100 & 4.950 & 506 & 0,10 \\
10 & 100 & 10 & 100 & 4.950 & 450 & 0,09 \\
\hline 10 & 100 & 10 & 100 & 4.950 & 450 & 0,0909 \\
10 & 200 & 20 & 200 & 19.900 & 1.900 & 0,0955 \\
10 & 300 & 30 & 300 & 44.850 & 4.350 & 0,0970 \\
10 & 400 & 40 & 400 & 79.800 & 7.800 & 0,0977 \\
10 & 500 & 50 & 500 & 124.750 & 12.250 & 0,0982 \\
10 & 600 & 60 & 600 & 179.700 & 17.700 & 0,0985 \\
10 & 700 & 70 & 700 & 244.650 & 24.150 & 0,0987 \\
10 & 800 & 80 & 800 & 319.600 & 31.600 & 0,0989 \\
10 & 900 & 90 & 900 & 404.550 & 40.050 & 0,0990 \\
10 & 1000 & 100 & 1000 & 499.500 & 49.500 & 0,0991 \\
\hline
\end{tabular}

$\mathrm{k}_{\mathrm{i}}=$ jumlah straw pada pejantan ke-i (dosis); $\mathrm{N}_{M P}=$ jumlah kombinasi perkawinan pada tetua; $\mathrm{N}_{\mathrm{MG}}$ = jumlah kombinasi perkawinan pada generasi pertama; $\mathrm{N}_{\mathrm{MK}}=$ jumlah kombinasi perkawinan inbreeding. *asumsi $\mathrm{N}_{\mathrm{Str}}=\mathrm{N}_{\mathrm{D}} ; S / C=1.00$; nilai $\mathrm{k}_{\mathrm{i}}$ setiap pejantan sama besarnya

\section{Simpulan}

Hasil penelitian menunjukkan bahwa formula matematika yang diperoleh secara trial and error method melalui simulasi data telah sesuai dengan konsep teori inbreeding dalam ilmu pemuliaan ternak. Formula matematika yang diperoleh pada penelitian ini selanjutnya dapat bermanfaat bagi akademisi untuk menambah wawasan. Bagi stakeholder seperti institusi penghasil straw (BBIB), hasil penelitian ini berguna untuk merencanakan pemeliharaan pejantan dan produksi straw dalam jangka panjang. Selain itu, hasil penelitian ini juga berguna untuk pengembangan Ilmu Pemuliaan Ternak di Indonesia.

\section{Daftar Pustaka}

[1] W. Hardjosubroto, Aplikasi Pemuliabiakan Ternak di Lapangan. Jakarta: Gramedia Widiasarana, 1994.

[2] E. J. Warwick, J. M. Astuti, and W. Hardjosubroto, Pemuliaan Ternak. Yogyakarta: Gadjah Mada University Press, 1990.

[3] Pollet, Penggunaan Metode Statistika Untuk Ilmu Hayati. Yogyakarta: Gadjah Mada 
University Press, 1994.

[4] Anonimus, "Laporan Tahunan BPPIBT-SP Ciamis, Jawa Barat," Dinas Ketahanan Pangan dan Peternakan Provinsi Jawa Barat, Bandung, 2015.

[5] W. P. B. Putra, S. Said, and A. Sudiro, "Pengaruh jumlah pejantan dan induk serta nilai heritabilitas terhadap nilai kemajuan genetik pada sapi Sumba Ongole: Studi simulasi data,” in Prosiding Seminar Nasional Perhimpunan Ilmu Pemuliaan Indonesia (PERIPI), 2017, pp. 600-608.

[6] Y. Duma and T. Mobius, "Potensi respon seleksi sifat pertumbuhan sapi Brahman Cross di ladang ternak Bila River Ranch, Sulawesi Selatan,” in Prosiding Seminar Nasional Sapi Potong, 2008, pp. 216-224.

[7] W. P. B. Putra, Sumadi, T. Hartatik, and H. Saumar, "Potensi respon seleksi sifat pertumbuhan sapi Aceh,” JITV, vol. 19, pp. 248-256, 2014. 